\title{
Narracje podręcznikowe Profesor Bożeny Chrząstowskiej
}

\section{Textbook Narrations by Professor Bożena Chrząstowska}

\author{
|Maciej Wróblewski \\ Uniwersytet Mikołaja Kopernika Toruniu \\ IORCID: 0000-0002-6386-7168
}

\begin{abstract}
The main aim of an article is an analysis of the textbooks of the Polish history literature course in a high school. Bożena Chrząstowska's textbooks Starożytność - oświecenie (1987) as well as Literatura współczesna (1992) combine structuralism tradition and new tendencies in Polish education which are oriented to the esthetic expectation of the students and also their intellectual skills. At the beginning of this article the author focuses on Chrząstowska's notion of the literature works reading by students which she demonstrated in the article Polonistyka szkolna $w$ procesie komunikacji literackiej (1977). During the next decade Chrząstowska's didactic proposals partly turned to new direction including a "center-anthropological" orientation in educational process but she firmly expressed necessity of rationalization of text reading in school. Chrząstowska's textbooks are the crucial didactic proposals which supported students during the process of building their reading skills, mainly, interpretation of literary works. Thanks to these abilities young people - according to Professor Chrząstowska - will be able to make aesthetic choosing in the future.
\end{abstract}

Key words: high school, Polish literary course, literary knowledge, structuralism

Streszczenie: Przedmiotem artykułu jest analiza podręczników do nauki historii literatury autorstwa Bożeny Chrząstowskiej. Zarówno Starożytność - oświecenie (1987), jak i Literatura współczesna (1992) są przykładem łączenia tradycji strukturalistycznych z nowymi, uwzględniającymi oczekiwania i możliwości intelektualne młodego odbiorcy. Punktem wyjścia podjętych rozważań są ustalenia Chrząstowskiej na temat warunków czytania tekstu w przestrzeni edukacyjnej, które zostały przedstawione w artykule Polonistyka szkolna w procesie komunikacji literackiej z 1977 roku. Od końca lat 80. propozycje metodyczne Chrząstowskiej zmierzają w nowym kierunku, choć zarazem Profesor nie traci z pola widzenia konieczności racjonalizacji aktu lektury w szkole. Mimo że Chrząstowska wprost nie opowiadała się za modelem antropocentrycznym edukacji polonistycznej, to jej postulat odchodzenia od szkolnego encyklopedyzmu na rzecz kształcenia umiejętności czytelniczych, a w dalszej perspektywie także dokonywania przez młodego człowieka wyborów aksjologicznych, można uznać za ważny krok orientujący nauczanie w kierunku potrzeb człowiek estetycznych.

Słowa kluczowe: szkoła, edukacja polonistyczna, wiedza o literaturze, strukturalizm 
Niniejszy szkic składa się z dwóch części. W pierwszej, krótkiej, wyjaśniam pojęcie „narracja podręcznikowa” oraz prezentuję własne doświadczenia związane $\mathrm{z}$ wykonywaniem zawodu nauczyciela języka polskiego w latach 1993 - 1998 w toruńskich szkołach podstawowych oraz ponadpodstawowych. Był to okres, w którym po raz pierwszy - choć nie ostatni, jak się potem okazało - wykorzystywałem w codziennej pracy podręczniki szkolne oraz kompendia z zakresu literaturoznawstwa, autorką których była Profesor Bożena Chrząstowska ${ }^{1}$. W drugiej, zasadniczej części, będę starał się, uwzględniając perspektywę zamkniętej już własnej kariery nauczycielskiej i wciąż rozwijanych badań w zakresie dydaktyki polonistycznej, przyjrzeć się temu, w jaki sposób Profesor Chrząstowska projektowała narracje podręcznikowe.

\section{I.}

Pojęcie „narracje podręcznikowe” wymaga krótkiego komentarza po to, by czytelnik podążał za moim wywodem bez zbędnych wątpliwości odnośnie do tego, czym ona jest ${ }^{2}$. Najkrócej rzecz ujmując, stanowi ona odpowiednik tej narracji, z którą mamy do czynienia w wypadku utworu literackiego ${ }^{3}$. Różnica polega jednak na tym, że narracja podręcznikowa determinowana jest historycznym, a więc zmiennym charakterem literatury. Ujawnia się to w następstwie obecnych w niej opisów czy analiz procesów dziejowych, zjawisk i fenomenów estetycznych (prąd, kierunek, konwencja, gatunek, forma), w prezentowaniu konkretnych postaci życia literackiego (autor, czytelnik, krytyk, badacz, edytor, cenzor) oraz ich zmiennej roli. Zawiera ona także określone elementy dydaktyki ogólnej i szczegółowej, które rozpoznać można zarówno na poziomie koncepcji podręcznika, jak i rozwiązań

1 Interesujący opis funkcjonowania podręczników szkolnych Bożeny Chrząstowskiej przynosi książka Marii Kwiatkowskiej-Ratajczak Docenić szkołę. Dydaktyczna teoria i metodyczna praktyka. W rozdziale „Polonistyczny regres albo zawężanie uczniowskiej i nauczycielskiej swobody” Kwiatkowska-Ratajczak przypomniała, jak Profesor Chrząstowska potrafiła krytycznie odnieść się do swoich podręcznikowych narracji, które ocenie poddawali uczniowie. Bowiem w ostatecznym, polonistycznym rachunku - jak słusznie zauważyła Kwiatkowska-Ratajczak - chodzi o skuteczność w prowadzeniu dialogu między nauczycielem a uczniem o literaturze. W tym kontekście podręcznik spełnia funkcje służebne, a więc jego autorka bądź autor powinni uwzględniać i godzić perspektywę nauczycielską oraz uczniowską (Kwiatkowskiej-Ratajczak 2021, 33-48).

2 Charakterystyki podręcznika jako narzędzia kształcenia polonistycznego dokonał Zenon Uryga w artykule Podręcznik jako narzędzie kształcenia literackiego w szkole średniej (Uryga 1991). Wskazał w nim, że ten specyficzny rodzaj książki, łączącej funkcje użytkowe z autorskimi rozwiązaniami edytorsko-estetycznymi, pełni rolę wspierającą proces dydaktyczny oraz dostarcza podstawowego materiału merytorycznego. Z kolei Jolanta Nocoń w książce Podręcznik szkolny w dyskursie dydaktycznym - tradycja i zmiana zanalizowała strukturę podręcznika szkolnego, uwzględniając jego cztery aspekty: pragmatyczny, poznawczy, strukturalny oraz stylowojęzykowy (Nocoń 2009, 45-54).

${ }^{3}$ Dla jasności przedstawienia złożonych kwestii związanych z popularnością od kilku dziesiątków lat kategorii narracji w badaniach humanistycznych warto ujmować ją nie tylko w tradycyjny, literaturoznawczy sposób, ale także jako fenomen daleko wykraczający poza zainteresowania badaczy literatury, a więc socjologów, etnologów, historyków, politologów. „Ponadto współczesna teoria narracji nie tylko rozprzestrzeniła się na pozostałe dziedziny wiedzy, ale zarazem odsłoniła nowe wymiary swego przedmiotu badań. Odsłoniła i jednocześnie ucieleśniła w sobie dwa bieguny: jeden wspierający się na wymiarze poznawczym, drugi eksponujący aporie poznawcze i kryzys reprezentacji. (...) Narratologia literaturoznawcza zaczęła łączyć różne dyscypliny. Mówiąc inaczej, kategoria narracji, często wraz z literaturoznawczym oprzyrządowaniem, zajęła ostatnio jedno z miejsc zdecydowanie naczelnych $\mathrm{w}$ wielu dziedzinach nauk humanistycznych. (...) Ponadto oddać należne miejsce trzeba socjologii (...), a także psychologii (...) i psychologii społecznej” (Łebkowska 2010, 185-186). 
metodycznych w postaci tekstów sterujących, ćwiczeń, pomocy i wskazówek, sposobu wykorzystania warstwy graficznej (tabele, wykresy, mapy) i typograficznej. Jednym słowem narracja podręcznikowa bierze w pacht nie tylko to, co powszechnie uznaje się za tekst, ale także ikonografię (kopie zdjęć, obrazów, artefaktów). Zatem w odróżnieniu od narracji jako kategorii z zakresu poetyki omawiana postać, czy odmiana, powstaje na zasadzie autorskich uzgodnień kilku obszarów wiedzy: historycznoliterackiej, teoretycznoliterackiej, pedagogicznej, psychologicznej oraz związanej z dydaktyką szczegółową ${ }^{4}$. W pewnym stopniu pokrywa się z tym kulturowym fenomenem, który jest przedmiotem refleksji narratologów. Ponadto w jej definiowaniu należy uwzględnić głos autora podręcznika. Nie musi on ujawniać się wprost, ale zazwyczaj dzieje się to za pośrednictwem metatekstów włączonych w strukturę książki ${ }^{5}$. Chodzi tu o różnego rodzaju „wprowadzenia”, „wstępy”, „instrukcje”, w których autorzy wskazują możliwe i optymalne sposoby posługiwania się stworzonym przez siebie podręcznikiem. Na ten fakt zwracała uwagę Barbara Myrdzik, omawiając wymiar aksjologiczny podręczników do kształcenia literacko-kulturowego dla gimnazjum:

Autorzy poprzez sformułowania zawarte w programach i podręcznikach, dobór i układ tekstów, tytuły części i sekwencji oraz prowadzony dialog z wirtualnym uczniem (w komentarzach i innych formach perswazji) odwoływali się - moim zdaniem - do następujących koncepcji pedagogiki kultury: wychowania estetycznego (...), do nurtu edukacji kulturowo-antropocentrycznej, do koncepcji edukacji o inspiracji personalistyczno-wspólnotowej (Myrdzik 2003, 71-72).

Narracja podręcznikowa jest zatem świadectwem nie tyle obiektywnego czytania literatury, ile raczej autorskiego, noszącego znamiona zamierzenia w pewnym sensie zorientowanego subiektywnie. Koncepcja książki przeznaczonej do użytku uczniów wymaga bowiem pomysłowości i zrozumienia nie tylko oczekiwań szkoły jako instytucji edukacyjno-wychowawczej, ale także potrzeb wychowanków (Zujew 1986). Należy godzić wskazówki zawarte w podstawie programowej z aktualnymi badaniami literaturoznawczymi oraz z - coraz bardziej trudnym do zwerbalizowania od początku lat 90. - stosunkiem młodego człowieka do sztuki słowa i aktu lektury. Pisząc o „subiektywności” podręcznika, mam na uwadze przede wszystkim aspekt konstrukcyjny, w którym ujawnia się nie tylko typowa dla tego typu obiektów pragmatyka, ale również chęć autorskiego i estetycznego przełamania zastanych form przekazu wiedzy historycznoliterackiej. Oczywiście, wartość estetyczna podręcznika ujawniająca się na poziomie jego konstrukcji

\footnotetext{
${ }^{4}$ Dodać warto także warstwę ideologiczną (ideową), która w różnym stopniu i w różny sposób ujawnia się w szkolnych podręcznikach: „Przydatność podręcznika do propagowania zróżnicowanych przesłań ideowych w dyskursie edukacyjnym polega na tym, że wymiar perswazyjny mogą mieć wszystkie elementy jego struktury. Prymarne funkcje perswazyjne pełni przede wszystkim tekst główny - różnego rodzaju czytanki (zwłaszcza te pisane na zamówienie), poezja dydaktyczna czy specjalnie wyselekcjonowane teksty literackie” (Rypel 2012, 304).

${ }_{5} \mathrm{Na}$ marginesie rozważań warto stwierdzić, że wielu współczesnych autorów zamieszcza w podręczniku swoje zdjęcie z krótką notatką biograficzną, co czyni przekaz u swoich źródeł podmiotowym i organizuje cały proces dydaktyczny jako dialog ucznia z literaturą zapośredniczony właśnie przez podręcznik.
} 
oraz w warstwie edytorskiej zawsze służy wzmocnieniu jego funkcji edukacyjnej (zob. Podręczniki literatury w szkole średniej, 1991). Niemniej jednak, w polskim szkolnictwie od końca lat 90. zauważyć można proces estetyzacji narracji podręcznikowej. Ale to zupełnie inny wątek ${ }^{6}$.

Swoją nauczycielską karierę rozpoczynałem w roku 1993. Struktura szkolnictwa w Polsce miała wówczas postać sprzed zmiany ustrojowej. Ośmioklasowa szkoła podstawowa oraz czteroletnie liceum i pięcioletnie technikum (oraz dwuletnia zawodówka) tworzyły system, który - jak się wydawało - dobrze wypełniał edukacyjne zadania także w nowej społeczno-politycznej rzeczywistości, choć dostrzegano potrzebę zmian, by młode pokolenia Polaków zdobywały wiedzę i umiejętności w warunkach dostosowanych do zmieniającego się świata. Sprawa dotyczyła jednak, według mnie, treści programowych, strategii i metod nauczania, a nie systemu szkolnictwa. Dyskusje na ostatni z wymienionych tematów rozpoczęły się w łonie szeroko rozumianego środowiska związanego ze szkolnictwem, nie wyłączając nauczycieli akademickich, w połowie lat 90. Rezultatem tego procesu była reforma przeprowadzona przez ministra Ryszarda Handkego wprowadzająca między innymi gimnazja.

Pierwsze doświadczenia pedagogiczne, będąc polonistą, zdobywałem w okresie, w którym toczyła się ważna dyskusja nad tym, co należy zmienić w treściach programowych i metodach nauczania, by szkoła była przestrzenią wolnościowej dyskusji i efektywnie wspierała młodych ludzi w ich rozwoju. W swojej codziennej pracy z uczniami liceum (od klasy pierwszej do maturalnej) podręcznik był dodatkową pomocą dydaktyczną, a nie głównym narzędziem pracy. Dlatego też książka Bożeny Chrząstowskiej napisana wspólnie z Marią Adamczyk i Józefem Tomaszem Pokrzywniakiem Starożytność - oświecenie dobrze spełniała swoją rolę. Przede wszystkim pozwalała mi organizować pracę samodzielną uczniów z wykorzystaniem części „Kontynuacje i nawiązania” oraz „Konteksty”. Nie zawsze uczniowie przygotowywali wypowiedzi pisemne na dany temat, ale w inny sposób wykorzystywałem autorskie pomysły metodyczne Profesor Chrząstowskiej umieszczane pod kolejnymi częściami podręcznika. Niekiedy były one pomocne w formułowaniu tematów dłuższych tekstów uczniowskich, przybierających albo formę rozprawki szkolnej, albo - dla chętnych - eseju interpretacyjnego, w którym istotną rolę odgrywał związek wybranych utworów współczesnych z dziełami należącymi do klasyki polskiej i światowej. Ten sposób myślenia o edukacji literackiej, oparty na uwzględnianiu perspektywy współczesnej, był mi wówczas bliski, choć niekiedy

\footnotetext{
${ }^{6} \mathrm{Na}$ to, w sumie pozytywne, zjawisko zwracał uwagę Zenon Uryga, charakteryzując główne tendencje rozwoju „ruchu podręcznikowego” w związku ze zmianą struktury szkolnictwa w Polsce i pojawieniem się gimnazjum: „Objawia się zarazem - nieoczekiwanie dla kogoś, kto przywykł do szarych, byle jako wydanych książek szkolnych z niedawnej przeszłości - zdolność naszego przemysłu poligraficznego i spółek wydawniczych do produkowania podręczników imponujących poziomem edytorskim - barwnych, zaciekawiających i żywych w sposobach organizowania kontaktu z uczniowskim odbiorcą" (Uryga 2003, 36). Strona edytorska, w tym materiał ikonograficzny zawarty w podręcznikach, są przedmiotem rozważań J. Nocoń w książce Podręcznik szkolny w dyskursie dydaktycznym - tradycja i zmiana (Nocoń 2009, 219-248).
} 
brakowało mi w podręczniku Starożytność - oświecenie wykorzystania innych mediów, jak muzyka, film, komiks. Po sposobie czytania przez moich uczniów lektur zacząłem dostrzegać, że w ich świadomości coraz większą rolę odgrywa dynamicznie rozwijająca się w latach 90. polska literatura popularna, której autorzy często sprawnie potrafili wykorzystywać zarówno klasykę rodzimą, jak i światową.

\section{II.}

Po kilku latach pracy w szkole ponadpodstawowej rozpocząłem asystenturę w Zakładzie Metodyki Nauczania Literatury i Języka Polskiego w Instytucie Filologii Polskiej UMK w Toruniu. A zatem miałem możliwość przyglądać się systemowi edukacji, w tym przede wszystkim edukacji polonistycznej, z innej perspektywy. Profesor Władysław Sawrycki zachęcił mnie nadto do działalności w Towarzystwie Literackim im. Adama Mickiewicza, będącym wówczas znakomitą platformą współpracy uniwersytetu ze szkołą. Ale także dzięki TLiAM zacząłem uczestniczyć w dyskusjach nad tym, jak i czego w ramach godzin polskiego uczyć. We wrześniu roku 1997 jako delegat toruńskiego oddziału TLiAM brałem udział w spotkaniu, w którym głos w sprawie szkolnej polonistyki zabierali, między innymi, profesorowie: Teresa Kostkiewiczowa, Zenon Uryga i Bożena Chrząstowska. W pamięci szczególnie utkwiła mi wypowiedź Bożeny Chrząstowskiej, która wskazywała na potrzebę porzucenia dominującego wówczas encyklopedyzmu w nauczaniu polskiego na rzecz rozbudowanych kontekstów kulturowych, filozoficznych i historycznych $\mathrm{w}$ ramach kursu języka polskiego na poziomie szkoły ponadpodstawowej. Słusznie przekonywała, że należy większy nacisk położyć na tworzenie dogodnej dla uczniów platformy zdobywania umiejętności pracy z tekstem literackim. Mniej miejsca powinny zajmować, powiedzmy, upraszczając złożoną w sumie sprawę, fakty literackie. Trawestując jedno $\mathrm{z}$ haseł rozpalających dyskusję $\mathrm{w}$ międzywojniu na temat miejsca historii literatury w szkole, można rzec: mniej historii, więcej lektury (Uryga 1996).

Kwestię podniesioną przez Profesor Chrząstowską warto sprowadzić, uwzględniając realia ówczesnej edukacji polonistycznej, do kwestii zasadniczej, związanej z tym, jakiego typu mechanizmy intelektualne i emocjonalne powinien uruchomić w czasie lekcji nauczyciel, by efektywnie osiągnąć zakładane cele w zakresie wiedzy, umiejętności i wychowania (Myrdzik 1999). Doskonałym odzwierciedleniem proponowanej przez Chrząstowską strategii nauczania jest podręcznik Starożytność - oświecenie (Adamczyk, Chrząstowska, Pokrzywniak 1987). Dodać należy, że jego koncepcję metodyczną opracowała Chrząstowska, która tak jak w wypadku wprowadzania do polskich szkół narzędzi strukturalistycznych (Chrząstowska, Wysłouch 1978; Chrząstowska 1979) poszukiwała nowych rozwiązań metodycznych. W tym kontekście warto przypomnieć jej metodyczną propozycję odnoszącą 
się do efektywnego syntezowania wiedzy historycznoliterackiej na lekcjach polskiego. Wówczas także była to wskazówka nowa, opierająca się na rzetelnych badaniach naukowych (Chrząstowska, Pietrzykowska 1969). Mimo że wymienione publikacje dzieli od podręcznika wiele lat, to jednak wspólna dla nich jest perspektywa ujmowania relacji uczeń - przedmiot szkolny, którego pośrednikiem w edukacyjnym dialogu są nauczyciel oraz podręcznik. Warto przytoczyć fragment wprowadzenia zatytułowanego „Jak korzystać z podręcznika?":

Korzystajcie zatem z podręcznika mądrze, wybierając z niego to, co w procesie poszukiwania wiedzy będzie dla Was niezbędne. Różnorodne materiały w nim zawarte powinny służyć lekturze, tj. powinny ułatwić zrozumienie zarówno głosów przodków, jak i własnej tożsamości w świecie współczesnym. Dzięki „rozumiejącej" i pogłębionej lekturze zdobędziecie wyobrażenie o bogactwie naszej kultury, o ciągłości tradycji narodowej, poznacie historię idei i sztuki słowa (Adamczyk, Chrząstowska, Pokrzywniak 1987, 15).

Koncepcja tego i innych podręczników Chrząstowskiej opiera się na założeniu, że dialog ucznia z tekstem literackim - zapośredniczony czy organizowany przez nauczyciela - oparty powinien być na racjonalnych podstawach. To przede wszystkim akt świadomościowy, w którym wiedza o literaturze jest wyraźnie sfunkcjonalizowana („poetyka stosowana”). Zarazem dostrzegam w propozycjach metodycznych Bożeny Chrząstowskiej element podmiotowości, lokujący jej koncepcje niedaleko antropocentryzmu (Podmiotowy wymiar szkolnej polonistyki, 1998). Co prawda nie jest on zwerbalizowany, jak w wypadku książek Marii Jędrychowskiej czy Zofii Agnieszki Kłakówny, ale również w artykułach z lat 70. Chrząstowska uwzględnia uczniowską perspektywę widzenia literatury. Ponadto była jedną z tych osób, które pracowały nad określeniem tożsamości naukowej dydaktyki polonistycznej. W tym miejscu należy przypomnieć główne treści artykułu z końca lat 70. (Chrząstowska 1977, 113-146), będącego ważnym autorskim głosem w podniesionej sprawie. Rzecz można sprowadzić do dwóch zagadnień. Pierwsze to określenie konsekwencji relacji między dydaktyką polonistyczną a badaniami literackimi i językoznawczymi. Drugie zaś odnosi się do uczniowskiej obecności w procesie kształcenia kulturowo-literackiego (i językowego także) jako podmiotu samodzielnie dokonującego pewnych wyborów o charakterze intelektualnym i estetycznym. Obydwie sprawy wiążą się, o czym pisała Maria Jędrychowska, z samookreśleniem dydaktyki literatury i języka polskiego jako dyscypliny naukowej (Jędrychowska 1998).

Chrząstowska w przywołanym artykule rozwijała refleksję w kierunku wszechstronnej charakterystyki komunikacji literackiej w przestrzeni szkolnej, wymagającej odrębnego naukowego namysłu. Pisała, że odbiór dzieła literackiego przez uczniów przebiega w złożonych warunkach choćby dlatego, że uczestniczy w nim jako pośrednik nauczyciel, a także w jego ramach korzysta się z tekstów sterujących czy wspomagających

Polonistyka. Innowacje

Numer 14, 2021 
proces analizy, a następnie interpretacji utworu. W związku z tym właśnie mówiła o dwustopniowości komunikacji literackiej, w której aktywnymi podmiotami - o różnym statusie i funkcji - są uczeń i nauczyciel oraz autor i odbiorca. Z dzisiejszej perspektywy patrząc na ustalenia Chrząstowskiej, ważne i wciąż aktualne wydaje się to, że uczniowskie działania na tekście literackim, bez względu na jego rodzajową i gatunkową przynależność oraz stopień treściowej złożoności, nie mają charakteru stałego. Wraz z postępującą edukacją na poziomie szkoły podstawowej i ponadpodstawowej „problemowość interpretacji”, zdaniem Chrząstowskiej, powinna się zmniejszać (Chrząstowska 1977, 123-124). Choć kładła ona nacisk przede wszystkim na proces kształcenia świadomości i wiedzy literackiej oraz historycznoliterackiej, to dostrzegała fakt wówczas nie dla wszystkich oczywisty, że młody człowiek w szkole podejmuje się lektury także takiej, która nie uwzględnia niewprawnego, początkującego czytelnika. Tu istotną rolę wspierającą i motywującą pełni nauczyciel:

W dobrze zorganizowanej sytuacji dydaktycznej nauczyciel nie wpływa na ucznia bezpośrednio, działa poprzez zabiegi ułatwiające proces poznawczy (metody i formy organizacyjne); komunikat, jaki nadaje uczniom, ogranicza się do objaśnień kodu, który musi być wspólny dla nauczyciela i ucznia (Chrząstowska 1977, 126).

Co prawda Chrząstowska nie używa w artykule pojęcia „koncepcja antropocentryczna", ale wydaje się, że przez wyeksponowanie aspektu świadomościowego i intelektualnego procesu poznawania tekstu literackiego oraz przez charakterystykę odmienności komunikacji literackiej w szkole ze względu na udział w niej dwóch par podmiotów (a nie jednej) nadała dydaktyce polonistycznej cechy fenomenu determinowanego wolą człowieka. Szczególnie interesująco wypada fragment, w którym Profesor określa status ucznia jako podmiotu działającego, to znaczy podejmującego wysiłek, by zrozumieć konkretny utwór. W tym kontekście pisze o „podwójności” odbiorczej, co jest obserwacją interesującą i wartą komentarza. Otóż dla Chrząstowskiej uczeń porusza się w specyficznej (sztucznej) przestrzeni semiotycznej, jaką organizuje nauczyciel w ramach kształcenia literackiego. Po pierwsze bowiem staje on wobec obcości tekstu literackiego jako czytelnik, który w taki czy inny sposób reaguje na to, co jest przedmiotem lektury. Tu istotną rolę odgrywają zarówno kwestie intelektualne, jak i odnoszące się do sfery przeżyć. Chrząstowska w sposób wyraźny obu obszarów nie rozdziela, pokazując ich współobecność na lekcjach polskiego. Ważne jest to, że podkreśla znaczenie procesu przechodzenia ucznia w związku z lekturą od nieświadomości do świadomości kwestii, które odnoszą się do mnogich spraw związanych z literaturą jako dziedziną sztuki, ważnym elementem życia społeczno-kulturowego oraz integralnym składnikiem historycznych procesów estetycznych. Po drugie zaś uczeń wchodzi w interakcję z nauczycielem w związku z czytanym tekstem; ten fakt może być źródłem - jak to nazywa Chrząstowska - „szumów”, 
które powstają jako efekt „niezborności obydwu ról nadawczych: wobec dysharmonii w dwugłosie autora i nauczyciela” (Chrząstowska 1977, 127). Badaczka tej kwestii, interesującej i niebagatelnej, nie rozwinęła. Warto jednak dopowiedzieć, że chodzi przede wszystkim o aspekt podmiotowości nauczania, a więc respektowanie roli nauczyciela i ucznia, a także swoistości dzieła literackiego jako autorskiego głosu. Agnieszka Zofia Kłakówna ujęła dyskutowaną sprawę następująco:

Podmiotowość jako atrybut człowieka i funkcja wolności wymaga pielęgnacji i rozwijania. Szkoła jednak ani wobec nauczycieli, ani wobec uczniów nie może stawiać wyłącznie na respektowanie podmiotowych standardów widzenia świata i siebie. Może natomiast budować swą ofertę z nastawieniem na dominację podmiotowych standardów, które stanowią warunek humanistycznej mądrości i rozumnego korzystania z wolności eksponowanych tu jako edukacyjne cele. Kształcenie sprzyja wtedy wychowaniu, także w sensie „wydobywania na jaw cnót naturalnych” (Kłakówna 2003, 103).

Kwestia owych „szumów” bezpośrednio odnosi się do aranżowania przez nauczyciela komunikacji pedagogicznej i literackiej w taki sposób, by pierwsza wspierała drugą, a nie zastępowała. O ile nie mamy wątpliwości, co do pozycji w niej autora danego tekstu i samego tekstu, o tyle nauczyciel oraz, w pewnym stopniu, uczeń należą do podmiotów zmiennych, zajmujących pole tylko względnie określone. Chrząstowska tę dynamikę uwzględniła, podkreślając rolę nauczyciela w organizowaniu procesu nauczania, współtworzonego przez trzy grupy informacji: podstawowe, sterujące i kontrolne. Oczywiście, najważniejsze są informacje sterujące, gdyż - jak przekonywała Profesor - dzięki nim kształcenie umiejętności analizy i interpretacji, a w dalszej perspektywie sposobów rozumienia tekstu literackiego odbywa się przy aktywnym udziale ucznia. Tak rozumiana funkcja pedagoga nakłada na niego obowiązek racjonalizacji swoich działań i planowania poszczególnych lekcji literatury (Myrdzik 1999, 128). Bowiem głównym celem jest sprawienie, by młody człowiek samodzielnie dokonywał wyborów czytelniczych, a wraz z nimi estetycznych i aksjologicznych.

Dydaktyka literatury nie może się ograniczać do opisu zjawisk komunikacyjnych, ale wychodząc z założeń wartościujących musi podjąć istotny problem: jak przekształcić zapotrzebowanie czytelnicze młodzieży w zainteresowania estetyczne, w świadome wybory wartościujące. Przejście od kultury niskiej do kultury wysokiej, od lektury młodzieżowej lub lektury typu rozrywkowego do dzieła sztuki słowa odbieranych ze zrozumieniem - to cel kształcenia literackiego i jednocześnie otwarty problem badawczy, w którym nie można pomijać aktualnych potrzeb młodzieży i zakłóceń w zjawiskach odbioru (Chrząstowska 1977, 129-130).

Przywołane słowa, mimo że pochodzą sprzed ponad czterdziestu lat, nie tylko wpisują się w koncepcję antropocentryczną nauczania, ale także są świadectwem racjonalnego podejścia do kwestii edukacyjnych. Bo oto Chrząstowska przekonuje, że lekcje literatury pełnią ważną funkcję kulturową i są obarczone powinnościami formacyjnymi, ale przede wszystkim 
zwrócone są ku przyszłości ucznia, który powinien mieć przynajmniej podstawowe kompetencje interpretacyjno-analityczne, przekładające się na świadomą postawę wobec różnych zjawisk artystycznych. Być może Chrząstowska nie w pełni zgodziłaby się na wpisywanie jej propozycji metodycznych do koncepcji antropocentrycznej, gdyż istotny był dla niej sposób rozumienia tekstu i efektywność użycia narzędzi poetyki (poetyki stosowanej). Ale zarazem już we wstępnym, zorientowanym strukturalistycznie ujęciu, uwzględniającym potrzeby ucznia, w tym czytelnicze (szerzej: estetyczne), dostrzec można te elementy, które w latach 90. będą dominowały. Nieco odmiennie sprawę tę referuje Kłakówna (Kłakówna 2003, 169-201). Sądzę jednak, że Chrząstowska w większym stopniu podkreślała znaczenie kształtowania wiedzy z zakresu poetyki i teorii literatury oraz wskazywała na konieczność pracy systematycznej w tym zakresie niż traktowania tych kwestii w sposób przygodny. Na ten fakt zwracała uwagę Maria Kwiatkowska-Ratajczak:

Warto przypomnieć, że w centrum zainteresowań metodycznych samej Chrząstowskiej była teoria dzieła zorientowana na odbiór utworu przez ucznia w określonym wieku, w konkretnym zespole, z konkretnym doświadczeniem kulturowym (Kwiatkowska-Ratajczak 2021, 14).

Ostatecznie cel wydaje się, jeśli nie tożsamy, to w wielu punktach zbieżny z koncepcją antropocentryczną. Proponowana przez nią w podręcznikach Starożytność - oświecenie oraz Literatura współczesna (Chrząstowska, Wiegandtowa, Wysłouch 1992) strategia poznawania zjawisk literackich jest tego potwierdzeniem. W dalszej części artykułu chciałbym zanalizować autorską narrację metodyczno-literaturoznawczą Chrząstowskiej.

Zacznę od obserwacji poniekąd banalnej, ale jednak dla dalszych rozważań istotnej. Podręcznik Starożytność - oświecenie, obejmujący okres dwóch i pół tysiąca lat, został rozpisany na trochę ponad pięciuset stronach, zaś podręcznik Literatura współczesna, obejmujący czterdzieści pięć lat, liczy blisko czterysta. Oczywista dysproporcja nie tylko wynika z przyjętego założenia, iż szczegółowość wiedzy maturzysty odnośnie do literatury współczesnej powinna być większa niż w wypadku piśmiennictwa dawnego, ale także - jak sądzę - obfitość materiału literackiego publikowanego po 1945 roku oraz waga problemów przez pisarzy podejmowanych może mieć związek z otaczającą młodego człowieka rzeczywistością. Nie znaczy to jednak, że Chrząstowska, wraz z zespołem piszącym podręcznik do nauki literatury dawnej, nazbyt powierzchownie potraktowali przeszłość, która ostatecznie w części stanowi fundament kultury Zachodu, ale wyszli ze słusznego założenia, że młodym ludziom warto objaśniać to, co stanowi nasze dziedzictwo i buduje kanon kulturowy językiem współczesnym. Ujmując sprawę z perspektywy nauczyciela, pracującego z licealistami w połowie lat 90., taka koncepcja edukacji literackiej była najbardziej efektywna i zarazem pozwalała przeciągać dodatkowe nici nawiązań czy też 
wprowadzać inne od zaproponowanych konteksty. W praktyce okazywało się, że czytam wraz z uczniami literaturę dawną za pośrednictwem głosów współczesnych - czy to Tadeusza Różewicza, czy też Jana Błońskiego. Obcość literatury dawnej, wynikająca z języka, formy, sposobu rozumienia świata - w tym człowieka - była wówczas w szkole trudna do pokonania dlatego, że dość szybko zmieniał się wokół młodych ludzi system komunikacji, zaczęła pojawiać się tłumaczona i rodzima literatura popularna, inne media dość agresywnie zaczęły organizować na swój sposób kulturową przestrzeń (telewizja, internet). Czytanie stawało się na moich oczach nie tyle kulturową powinnością osoby aspirującej do bycia maturzystą, ile raczej przykrym - w niemałej liczbie przypadków - obowiązkiem kwestionowanym także przez otaczającą nas rzeczywistość. W takiej sytuacji podręcznik, zawierający fragmenty tekstów literackich, dla wielu uczniów był pierwszą i jedyną formą kontaktu z literaturą. A zatem Chrząstowskiej koncepcja narracji o literaturze dawnej do pewnego stopnia pozwalała nauczycielowi zakreślać szerszy horyzont czytelniczy niż tylko ten ograniczony cezurami, w których mieściła się literatura dawna - od antyku grecko-rzymskiego do oświecenia.

Podręcznik Starożytność - oświecenie zawiera pięć rodzajów tekstów: pierwszy ma charakter historyczny i historycznoliteracki (tablica chronologiczna, wprowadzenie), na kolejny składają się fragmenty utworów, trzeci zaś to „kontynuacja i nawiązania”, potem następuje część zatytułowana „konteksty interpretacyjne”, a na końcu Chrząstowska umieściła „ćwiczenia lekturowe”, „pytania kontrolne” i „wskazówki bibliograficzne”. Mamy zatem taką strukturę, która $\mathrm{w}$ ogólnym zarysie odpowiada trzem kategoriom informacji (podstawowe, sterujące i kontrolne), o których pisała w omówionym artykule z końca lat 70. Poza istotnymi informacjami o charakterze historycznoliterackim $\mathrm{w}$ obu podręcznikach istotny element narracji to pojęcia i terminy z zakresu poetyki, czego odzwierciedleniem są graficznie wydzielone cząstki „Zapamiętaj!”; jej perswazyjny charakter tytułu zakończonego wykrzyknieniem podkreśla wagę tego, co się tam znalazło. Wskazywanie na „charakterystyczne dla epoki pojęcia”, z jednej strony, pozwala jednym rzutem oka uczniowi zorientować się w tym, co ważne, ale z drugiej, zwalnia go z konieczności wypracowania - na podstawie wiedzy wyniesionej z podręcznika jak i z lekcji polskiego - obrazu danej epoki. Nie czynię zarzutu Autorce, ale dostrzegam pewną niekonsekwencję między wyłożoną we wprowadzeniu ideą podręcznika, którą można zamknąć w słowie „samodzielność”, a jego konstrukcją, zawierającą jednoznaczne wskazówki dotyczące hierarchii ważności podejmowanych w narracji kwestii. W kontekście dyskutowanych spraw warto przytoczyć słowa Bożeny Chrząstowskiej z „Przedmowy” do podręcznika dla maturzystów:

Jak zatem korzystać z podręcznika? Najpierw - korzystać samodzielnie, nie czekając tylko na sugestie i polecenia nauczyciela. Korzystać często. Wracać do już 
poznanych partii materiału; podręcznik jest tak skonstruowany (tytuły, śródtytuły, pytania, tabelki, ramki), że materiał „sam wejdzie do głowy”, bez osobnego „wkuwania”. Zaczynać lekturę od tekstu literackiego i szukać potrzebnych informacji w różnych partiach podręcznika, posługując się indeksem (Chrząstowska, Wiegandtowa, Wysłouch 1992, 9).

Autorka podkreślała nadto prymat uważnej lektury i związanej z nią refleksji nad systemowo przyswojoną wiedzą z zakresu historii literatury. A zatem samodzielność, która wydaje się w tym wypadku oczywistością ze względu na wiek i doświadczenie czytelnika, pojawia się jako główne hasło, rodzaj pobudki wybijającej leniwych uczniów z marazmu nieczytania. To co prawda jedynie podręcznikowe założenie, ale przecież tego typu książkę czyta się na różnych poziomach, w pewnym sensie odbiorca zostaje przez Chrząstowską zachęcony do tego, by nią manipulować w taki sposób, by uzyskać odpowiedni poznawczy efekt. Jej dwudzielna budowa („Fakty i problemy”, „Teksty i konteksty”) organizuje narrację dydaktyczno-literaturoznawczą wokół określonych (wskazanych) problemów polskiego życia literackiego między 1945 a 1989 rokiem. Nie rozstrzygam zasadności zaprezentowanych zjawisk w trzech rozdziałach składających się na pierwszą część Literatury współczesnej, której narracja kończy się na okresie stanu wojennego. Bardziej interesujące jest to, w jaki sposób autorki myślały o literaturze jako pewnym kulturowym fenomenie prezentowanym młodemu czytelnikowi. Przede wszystkim rzuca się w oczy rola biografii twórcy oraz znaczenie kwestii z zakresu poetyki oraz teorii literatury w sposobie tłumaczenia uczniom złożonych i w sumie niejednoznacznych (np. okres socrealizmu) zjawisk polskiego życia literackiego w kraju i na emigracji. Ponadto zastosowane w narracji podręcznikowej wykresy, schematy, tabele odzwierciedlają strukturalistyczne myślenie o twórczości, choć autorki nie zrezygnowały z kontekstu historycznego i filozoficznego. Odrębny rozdział, zatytułowany „Literatura wobec innych sztuk”, należy uznać także jako naszkicowany medialny kontekst przemian literatury po 1945 roku, choć zabrakło tu i telewizji, i komiksu, wchodzących w różne alianse $\mathrm{z}$ belle lettre. Zatem jako punkt wyjścia do budowania wiedzy o literaturze omawiany podręcznik stanowi interesujący przykład godzenia aspiracji historyczno- i teoretycznoliterackich z koniecznością motywowania ucznia do samodzielnej lektury, a w dalszej perspektywie wyrabiania w sobie - o czym Chrząstowska pisała w artykule Polonistyka szkolna - smaku estetycznego.

Dialog między uczniem a utworem literackim zapośredniczony przez podręcznik, a nie tylko przez nauczyciela, w ujęciu Bożeny Chrząstowskiej oparty jest na kilku zasadach. Pierwsza dotyczy lektury jako procesu świadomego i racjonalnego, a więc sprawa przeżycia estetycznego, emocji, poszukiwania w tekście odpowiedzi na osobiste pytania młodego człowieka w narracji dydaktyczno-literaturoznawczej zostaje przesunięta na plan dalszy. Druga związana jest z uwypukleniem funkcjonalności 
poetyki stosowanej, ale także wiedzy z zakresu teorii literatury, by akty analityczno-interpretacyjne nosiły znamiona badawczego poszukiwania, a nie wywołanej estetycznymi bodźcami impresji. Konsekwencją tego jest kolejna zasada, którą można określić historycznoliteracką, to znaczy lektura utworu dawnego czy współczesnego powinna być oparta na znajomości właściwego kontekstu, nie wyłączając filozoficznego i estetycznego. Ostatnia zaś zasada, szczególnie wyraźnie obecna w Literaturze współczesnej, opiera się na autorskim, a więc do pewnego stopnia subiektywnym - choć opartym na badaniach literaturoznawczych - ujmowaniu polskiego piśmiennictwa. I nie chodzi tu o dobór nazwisk pisarzy i ich utworów, ale przede wszystkim o wyznaczenie dla literatury polskiej po 1945 ważnych punktów, wokół których zogniskowana została podręcznikowa narracja. Wymieńmy je z rozdziału pierwszego: „Wojna i tak zwany świt pokoju”, „Socrealizm”, „Rozkwit literatury emigracyjnej po roku 1951”, „Przełom październikowy”, „Nasza mała stabilizacja”, „Marzec 1968” oraz „Przełom 1976"). Wskazane tytuły są - w większości - funkcjonującymi w refleksji literaturoznawczej hasłami, które w metaforyczny sposób określają dane zjawisko, a zatem nie tyle są pozbawionymi pewnego znaczeniowego naddatku nazwami, ile właśnie autorską wizją.

Podręcznikowe narracje dydaktyczno-literaturoznawcze Profesor Bożeny Chrząstowskiej łączą tradycyjne podejście do literatury jako ważnego narzędzia edukacyjno-wychowawczego z próbą wyjścia w stronę dialogu opartego na autorskim, a więc subiektywnym, widzeniu polskiej literatury. To, w jakim stopniu tradycyjne badania historycznoliterackie oraz uniwersytecka wiedza z zakresu poetyki determinowały sposób budowania narracji podręcznikowej, trudno precyzyjnie ocenić. Z pewnością był to ważny i dobrze umocowany w praktyce polonistycznej punkt wyjścia metodycznych propozycji Chrząstowskiej. Zarazem jednak od początku lat 90. następowała intensywna kulturowa przemiana kolejnych pokoleń uczniów ${ }^{7}$. Zapewne mimowolnie przesuwali swoje zainteresowania w kierunku różnych dziedzin kultury popularnej, stawali się trochę mniej czuli na tekst literacki, poszukując innych estetycznych bodźców, w tym przede wszystkim wizualnych i audialnych. Podręczniki współtworzone przez Profesor Bożenę Chrząstowską nie zawierają zbyt wielu odniesień do innych niż tekstowe mediów. Stanowią jednak bardzo interesujący przykład próby przełamywania tradycyjnych strategii nauczania za sprawą rozbudowywania kontekstów interpretacyjnych oraz podkreślania znaczenia ucznia jako podmiotu, który - przy walnym współudziale nauczyciela - powinien dążyć do tego, by intelektualnie dojrzeć. Chciałbym zamknąć artykuł słowami

${ }^{7}$ Pisał o tym fakcie Zenon Uryga w przywoływanej już książce Godziny polskiego. W związku z charakterystyką różnych form historycznoliterackiej informacji stwierdzał, co następuje: „Trzeba powiedzieć wyraźnie, że nauczyciel literatury w szkole średniej staje obecnie (rok 1996 - przyp. M. W.) u progu nieodwracalnego procesu różnicowania się treści i dróg kształcenia. Zakres i sposób przekazywania informacji dotyczących historycznoliterackiego tła lektury jest niewątpliwie jednym z tych problemów, które wymagają od niego samodzielnych decyzji, podejmowanych ze świadomością własnej koncepcji kształcenia oraz rozpoznaniem potrzeb, możliwości uczniów i sytuacji dydaktycznej" (Uryga 1996, 179). 
Profesor Bożeny Chrząstowskiej, która podkreślała fundamentalne znaczenie roli wychowawczej edukacji polonistycznej, co wydaje się poniekąd oczywistością, ale wciąż - jak sądzę - wymaga namysłu i krytycznej refleksji, by zamierzenie to było po prostu skuteczne.

Dziś [koniec lat 90. - M.W.] już nie mamy wątpliwości, że najważniejszym zadaniem szkoły jest wychowanie młodego człowieka. Rozmywanie wartości w świecie kultury masowej, odrzucenie tradycji, sprowadzenie jej wyłącznie do „repetycji” uprawianych w literaturze w celu zabawy, względność i nieprzestrzeganie norm moralnych, zanik autorytetów, zastąpienie Boga i wszelkiej świętości bożyszczem biznesu, pieniądza, sukcesu - wszystko to sprawia, że świat staje się groźny i nieprzewidywalny. Uznanie celów wychowawczych za nadrzędne lub wyraźniej - koronne - ma dzisiaj szczególne uzasadnienie i motywacje (Chrząstowska 1999, 272).

\section{Bibliografia:}

Adamczyk Maria, Chrząstowska Bożena, Pokrzywniak Józef Tomasz, 1987, Starożytność - oświecenie. Podręcznik literatury dla klasy pierwszej szkoły średniej, wyd. 1., Warszawa.

Chrząstowska Bożena, Pietrzykowska Anna, 1969, Pomoce naukowe na lekcjach poświęconych syntezie historycznoliterackiej, Chrząstowska B. (red.) Pomoce naukowe $w$ pracy polonisty $w$ szkole średniej. Zbiór artykułów metodycznych, Warszawa, s. 77-116.

Chrząstowska Bożena, 1977, Polonistyka szkolna w procesie komunikacji literackiej, „Pamiętnik Literacki”, z. 3, s. 113-146.

Chrząstowska Bożena, 1979, Teoria literatury w szkole. Z badań nad recepcja liryki w szkole, Warszawa.

Chrząstowska Bożena, Wysłouch Seweryna, 1978, Poetyka stosowana, Warszawa.

Chrząstowska Bożena, Wiegandtowa Ewa, Wysłouch Seweryna, 1994, Literatura wspótczesna. Podręcznik dla klas maturalnych, wyd. 2., Poznań.

Chrząstowska Bożena, 1999, Konteksty aksjologiczne, „Polonistyka”, nr 5, s. 272-279.

Jędrychowska Maria, 1998, Najpierw człowiek. Szkolna edukacja kulturowo-literacka a problem kształcenia dydaktycznego polonistów. Refleksja teleologiczna, Kraków.

Kwiatkowska-Ratajczak Maria, 2021, Docenić szkołę. Dydaktyczna teoria i metodyczna praktyka, Poznań.

Łebkowska Anna, Narracja, 2010, Markowski M.P., Nycz R. (red.), Kulturowa teoria literatury. Główne pojęcia i problemy, Kraków, s. 181-215.

Myrdzik Barbara, 1999, Rola hermeneutyki w edukacji polonistycznej, Lublin.

Myrdzik Barbara, Koncepcja kształcenia kulturowego na przykładach wybranych podręczników dla gimnazjum, 2003, Podręcznik jako narzędzie kształcenia polonistycznego w gimnazjum, Kosętka H., Uryga Z. (red.), Kraków.

Nocoń Jolanta, 2009, Podręcznik szkolny $w$ dyskursie dydaktycznym - tradycja i zmiana, Opole. 
Podmiotowy wymiar szkolnej polonistyki: materiały z konferencji „Antropocentryczno-kulturowy nurt w kształceniu polonistycznym” (Kraków, 23-24 października 1995), Uryga Z. (red.), Kraków.

Rypel Agnieszka, 2012, Ideologiczny wymiar dyskursu edukacyjnego na przykładzie podręczników języka polskiego z lat 1918 - 2010, Bydgoszcz.

Uryga Zenon, Podręcznik jako narzędzie kształcenia literackiego $w$ szkole średniej, 1991, Podręczniki literatury w szkole średniej. Wczoraj-dziś - jutro, Chrząstowska B. (red.), Poznań.

Uryga Zenon, 1996, Godziny polskiego. Z zagadnień kształcenia literackiego, Warszawa - Kraków.

Uryga Zenon, 2003, Współczesna generacja podręczników literatury dla gimnazjum, w: Podręcznik jako narzędzie kształcenia polonistycznego w gimnazjum, Kosętka H., Uryga Z. (red.), Kraków.

Zujew D. Dymitr, 1986, Podręcznik szkolny, Żygierewicz J. (przeł.), Warszawa.

\section{O Autorze:}

Maciej Wróblewski - literaturoznawca, adiunkt, kierownik Pracowni Badań Kultury i Literatury dla Dzieci i Młodzieży oraz Katedry Antropologii Literatury i Nowych Mediów na Wydziale Humanistycznym Uniwersytetu Mikołaja Kopernika w Toruniu. Publikował swoje artykuły w językach polskim i angielskim, m. in. w „Pamiętniku Literackim, „Przeglądzie Humanistycznym”, „Archiwum Emigracji”, „Ruchu Literackim”, „Polonistyce”, „Literaturze Ludowej”, „Childhood Remix Journal”, „Filoteknosie”. Jest pomysłodawcą i redaktorem naukowym serii „Biblioteczka Dziecięca”, w której do tej pory ukazały się 4 tomy poświęcone literaturze oraz sztuce dla dzieci i młodzieży. Dotychczas wydał 6 monografii: Proza niefikcjonalna $w$ edukacji polonistycznej ucznia szkoły średniej [1855-1939] (2003), Jan Rymarkiewicz - XIX-wieczny humanista (2006), Czytanie przyszłości. Polska fantastyka naukowa dla młodego czytelnika (2009), Człowiek $w$ przestrzeniach szkoły. Studium antropologiczne (2014), Literatura i maszyna (2015) oraz Doświadczanie dzieciństwa. Studium z antropologii literatury (2019). W roku 2021 w jego opracowaniu ukazała się książka „a małe dzieci do ognia wrzucali". Antologia wypracowań szkolnych (1945 - 1946) na temat II wojny światowej. Od roku 2018 pełni obowiązki przewodniczącego jury Nagrody Literackiej im. Jerzego Żuławskiego. 